\title{
Do pre-service teachers feel ready to teach with digital technologies? A study in two teacher training institutions in Costa Rica
}

\author{
Os professores em formação se sentem prontos para ensinar com tecnologias digitais? Um em duas \\ instituições de formação de professores na Costa Rica
}

¿Los profesores en formación se sienten preparados para enseñar con tecnologías digitales? Un estudio en dos instituciones de formación docente en Costa Rica

Received: 12/22/2020 | Reviewed: 12/22/2020 | Accept: 01/01/2021 | Published: 01/04/2021

\author{
Christiane Caneva \\ ORCID: https://orcid.org/0000-0002-4559-7424 \\ Haute école pédagogique Vaud, Switzerland \\ E-mail: christiane.caneva @hepl.ch
}

\begin{abstract}
This study aims to identify both the level and frequency of digital technology use and perceived self-efficacy levels of pre-service teachers $(n=341)$. We collected data in Costa Rica through a survey during the 2016-2017 academic year; the survey includes closed-ended items on the use and frequency of digital technologies along with open-ended questions. Findings suggest that a majority of pre-service teachers frequently use digital technologies for both professional and private use and specifically the mobile phone and social media. Results further suggest they find themselves self-efficacious in the use of "traditional" digital technologies that are also used in teacher training by professors/teacher trainers such as laptop, email and video. They are less confident in using mobile phones and social media for teaching even though they use them extensively for their professional development.
\end{abstract}

Keywords: Pre-service teacher training; Higher education; Self-efficacy; Digital technologies; Middle income countries; Costa Rica.

\section{Resumo}

Este estudo tem como objetivo identificar o nível e a frequência de uso da tecnologia digital e os níveis de autoeficácia percebidos de pelos professores em formação $(n=341)$. Coletamos dados na Costa Rica por meio de uma pesquisa durante o ano acadêmico de 2016-2017; a pesquisa inclui itens questões fechadas sobre o uso e a frequência das tecnologias digitais e a frequência, juntamente com perguntas abertas. Os resultados sugerem que a maioria dos professores em formação usa frequentemente usa tecnologias digitais para uso profissional e privado e, especificamente, o telefone celular e as mídias sociais. Os resultados sugerem ainda que eles se consideram autoeficientes no uso de tecnologias digitais "tradicionais" que também são utilizadas na formação por formadores de professores, como laptop, e-mail e vídeo. Eles têm menos confiança no uso de telefones celulares e mídias sociais para ensinar, embora os usem extensivamente para seu desenvolvimento profissional.

Palavras-chave: Formação inicial de professores; Ensino superior; Autoeficácia; Tecnologias digitais; Países de renda média; Costa Rica.

\section{Resumen}

Este estudio tiene como objetivo identificar tanto el nivel y la frecuencia de uso de la tecnología digital como los niveles de autoeficacia percibida de los docentes en formación $(\mathrm{n}=341)$. Recolectamos datos en Costa Rica a través de una encuesta durante el año académico 2016-2017 sobre el uso y frecuencia de las tecnologías digitales. Los resultados sugieren que la mayoría de los profesores en formación utilizan con frecuencia tecnologías digitales tanto para uso profesional como privado y, específicamente, el teléfono móvil y las redes sociales. Los resultados sugieren además que se encuentran autoeficaces en el uso de tecnologías digitales "tradicionales" que también son utilizadas en la formación por formadores de profesores, como computadoras portátiles, correo electrónico y video. Tienen menos confianza en el uso de teléfonos móviles y redes sociales para la enseñanza a pesar de que los utilizan mucho para su desarrollo profesional.

Palabras clave: Formación inicial docente; Educación superior; Autoeficacia; Tecnologías digitales; Países de ingresos medios; Costa Rica. 


\section{Introduction}

In this global Fourth Industrial Revolution, artificial intelligence, robotics, nanotechnology, and genetics research are accelerating the transformation of industries. Knowing how to use digital technologies is now critical, as more and more economic, health, cultural, social, and political information and services are provided online. However, the digital divide is widening at different levels in our society, whether in terms of access to computers and the Internet (first level divide) or ability to navigate the various uses (second level divide) (Schweitzer, 2018). Therefore, reducing the digital divide becomes an important democratic issue as the exercise of citizenship and civic participation increasingly mobilize digital skills.

The simple fact of owning a digital device does not automatically lead to possession of all its complex uses (Granjon, 2011). Neither does it presuppose possessing the skills necessary to benefit from it. Although the first level digital divide (access) is less of an issue today than it was in the past-even in non-industrialized countries - thanks to the initiatives of decision makers, educational organizations, or private companies (Roumell Erichsen and Salajan 2014), the second level divide (uses) persists (Ma, Vachon, \& Cheng, 2018). Within each country there might be digital inequalities related to population's socio-economic imbalances. Indeed, digital skills are unequally distributed and low-educated women are the most disadvantaged social group (Arroyo Prieto \& Valenduc, 2016). Although more and more seniors have access to digital technologies, there still persists a discrepancy between young and old in terms of ICT usage competency (Charmarkeh, 2015).

Therefore, it is imperative to develop digital skills today.

Beyond the democratic issue, several governments consider digital technologies to improve teachers' professional development. Distance or technology-mediated learning could also provide a wider access to education and offer a more personalized learning experience, improving education for a number of students. Although most teacher training institutions recognize the importance of using digital technologies to modernize and innovate teaching and learning, the integration of digital technology in teacher training is neither regular nor systematic. Vaillant (2013) asserts that this is due to the lack of clear policies with well-defined strategies and objectives. Another factor is teacher trainers having unfavorable attitudes regarding digital technologies (Caneva, 2019a).

However, for many young people from disadvantaged communities, school offers the only opportunity to acquire the digital skills necessary to evolve in our digital world. Therefore, it is vital for pre-service teachers to become digitally literate. Thus, two major arguments emerge from scientific literature. Firstly, integrating digital technologies into teacher training could reduce the digital divide and better prepare future generations. Secondly, it would improve the quality and relevance of teacher training.

\section{Implementing Digital Technologies in Teacher Training in Costa Rica}

Costa Rican government authorities are primarily interested in digital technologies to improve economic development and for the possibilities they offer to develop a more inclusive, fairer, and more innovative society that is committed to reducing the digital gap between those who are connected and those who are not (Ministerio de Planificación Nacional y Política Económica, 2014). Integrating digital technologies into education would guarantee its quality throughout the territory (Ministerio de Planificación Nacional y Política Económica, 2013). In Costa Rica, the quality of teacher training is challenging for different reasons. The main reasons are the absence of a uniform teacher training curriculum across the country, the strong presence of private universities, and teacher training policies that lack a long-term vision (Jiménez, 2014).

To improve the quality of education, the Ministry of Education promotes digital technologies through different initiatives specifically concerning in-service teachers' professional development. Concerning pre-service teachers' training, the responsibility for developing digital skills rests with teachers' training institutions. Therefore, they play a major role in 
developing students' digital skills, stimulating the development of critical thinking, creativity, and collaboration through the use of digital technologies. Nevertheless, curriculum for pre-service teachers training is obsolete (Consejo Nacional de Rectores, 2015). The last update at National University was in 2007 and at University of Costa Rica in 2008. In private universities, this dates back to a period between 1998 and 2005 (Caneva, 2019a).

\section{The challenges of using digital technologies in initial teacher training in low and middle income countries}

Digital technologies, specifically mobile devices, offer advantages in different fields in low and middle income countries (Furuholt \& Matotay, 2011). The spatiotemporal versatility specific to mobile devices allows pre-service teachers to train remotely, avoiding travel time to university. It is possible to reach marginalized communities where access to computers isn't guaranteed, but where, on the other hand, the mobile telephone is widely used (UNESCO, 2012).

The use of digital technologies also represents the advantage of expanding the types of training offered and enabling pre-service teachers to enroll in programs not offered locally, thereby promoting equal access and better equity in the distribution of knowledge (Brun, 2011). However, the global digital divide is affecting many low and middle income countries (Fuchs \& Horak, 2008). Some researchers claim that without technology, economic and social development will not be possible, and the divide with the countries of the North will widen further (Mugimu \& Ssebbunga-Masembe, 2011). However, there is also a digital divide within countries (Bornman, 2016). This gap is widening in terms of uses between passive consumers and those who can participate actively in the construction and sharing of knowledge on the Internet (Granjon, 2011). Indeed, certain skills are necessary to grasp the advantages offered by technologies and not every person has access to develop these skills.

Some concerns mainly affect the low and middle income countries, such as inadequate technical resources and infrastructure (blackouts, outdated equipment, slow Internet) and the lack of resources to buy the equipment (Prasojo, et al. 2018). This problem is compounded by teacher trainers being resistant to change (Caneva, 2019b). Additionally, some international projects are born as a response to an urgent need, and they are neither part of a clear vision of the government nor of a long-term integration policy.

After having discussed generally the advantages and disadvantages of digital technologies in the training of preservice teachers, we deal in the next section with the potential for digital technologies to improve their professional development.

\section{Using digital technologies for teacher training and professional development: developing collaboration}

Digital technologies can offer newer, more flexible, and more efficient ways of ensuring teachers' professional development (Baran, 2014). There are more and more MOOCs to learn to teach with digital technologies (Vivian, Falkner, \& Falkner, 2014), plus webinars and videoconferences to deepen themes of a discipline (Roy, 2018). Twitter has become the main network for exchange in education (Roy, 2018). Facebook groups have become an opportunity to engage in informal professional development (Cinkara \& Arslan, 2017). Online groups offer members the possibility to validate teaching materials, demonstrate the success of certain practices, and quickly access support (Kent, 2018).

In this way, mobile technologies improve collaboration (Baran, 2014). Collaboration is favored through tools such as wikis and database sharing (Aubusson, Schuck and Burden, 2009), which facilitate the exchange of practical experiences between beginners and experienced teachers and encourage collaborative problem solving. However, this possibility of collaboration is dependent on the technological equipment available at the place of the internship. Baran's (2014) systematic literature review on the use of mobile technologies for teacher training, however, highlights the gaps in research in order to propose theoretical and pedagogical models that could guide teacher trainers specifically in designing training experiences with 
mobile technologies. Caneva (2019b) also highlights the shortcomings of digital integration models in initial teacher training. The models are mostly unrelated to the needs of teacher training institutions.

In short, the scientific literature indicates that the use of digital technologies in initial training makes it possible to develop certain transversal skills essential to exercise the teaching profession, such as collaboration.

As one of the leading factors affecting the success of technology integration is teachers' beliefs about their own selfefficacy (Liu, Ritzhaupt, Dawson, \& Barron, 2017), this study examines pre-service teachers' needs and expectations concerning digital technologies and their use of digital technologies for educational purposes in both formal (university courses) and informal (private use) environment. This study seeks answers to the following questions:

1. What are pre-service teachers' digital technology frequency and use levels?

2. How do they perceive themselves in terms of their digital technology self-efficacy?

\section{Methodology}

The study group was formed of pre-service teachers from the preschool and primary school programs from two Costa Rican universities and professors/teacher trainers, directors of pre-service teacher programs and ICT managers. The choice of universities was determined based on two criteria for inclusion: (1) must be a public university; (2) must be offering a training program for preschool and elementary teachers. Only two of the country's five public universities met these criteria: University of Costa Rica and National University ${ }^{1}$.

Characteristics of the participants are indicated in Table 1.

Table 1. Information about participants $(n=341)$.

\begin{tabular}{|l|l|l|l|l|l|l|}
\hline \multicolumn{2}{|l|}{ Gender } & Age \\
\hline F & M & $17-19$ & $20-29$ & $30-39$ & $40-49$ & $50-59$ \\
\hline $\begin{array}{l}\mathbf{3 1 8} \\
(\mathbf{9 3 \%})\end{array}$ & $\begin{array}{l}23 \\
(7 \%)\end{array}$ & $\begin{array}{l}86 \\
(25 \%)\end{array}$ & $\begin{array}{l}241 \\
(71 \%)\end{array}$ & $\begin{array}{l}10 \\
(3 \%)\end{array}$ & $\begin{array}{l}(0.8 \%) \\
(0.2 \%)\end{array}$ \\
\hline
\end{tabular}

\begin{tabular}{|l|l|l|l|}
\hline Program & \multicolumn{3}{|c|}{ University } \\
\hline Preschool & Primary & UCR & UNA \\
\hline $\mathbf{1 8 0}$ & 161 & 179 & 162 \\
$\mathbf{( 5 3 \% )}$ & $(47 \%)$ & $(52 \%)$ & $(48 \%)$ \\
\hline
\end{tabular}

Source: Author.

The age category for the majority of participants (71\%) is between 20 and 29 years old. Of all participants, 318 (93\%) were female and $23(7 \%)$ were male. The University of Costa Rica (52\%) and National University (48\%) were almost equally represented. The participants were majoring in preschool education (53\%) and primary education (47\%). The largest percentage of participants was attending their first year of study (28\%), while the lowest percentage of participants corresponds

\footnotetext{
${ }^{1}$ The Instituto Tecnológico de Costa Rica participates partially in the training of teachers through the School of Mathematics (Escuela de Matemática) and the creation of a training program for the teaching of mathematics using computers (OEI and MEP, 2003). This very specialized training does not fit into our research objectives. Regarding the Universidad Estatal a Distancia, we did not take it into account for our research, since distance training and the use of digital technologies are the only training modality offered.
} 
to the fifth (optional) year (13\%).

\section{Data Collection Instruments and Analysis}

This exploratory study (Pereira, A.S. et al. 2018) followed mixed approach using both quantitative and qualitative research design (Pinard, Potvin, \& Rousseau, 2004) by administering a survey that we developed by adapting UNESCO ICT Competency Framework for Teachers (UNESCO, 2011).

Data collection took place during the 2016-2017 academic year. We distributed a questionnaire to 500 students out of the 646 registered for the preschool and elementary school teaching programs at the University of Costa Rica (San José campus) and the National University (Heredia campus). To ensure a sufficiently large sampling pool, the questionnaires were submitted to at least one group of students for each year of the "bachelor" and "licensure" programs. The survey was composed of six parts (Table 2).

Table 2. Survey Overview.

\begin{tabular}{|l|l|l|}
\hline Scale Construct Measure & No. items & Type of questions \\
\hline $\begin{array}{l}\text { I.General identification of } \\
\text { the subjects }\end{array}$ & 66 & Multiple choice \\
\hline II. Digital policy knowledge & 4 & Open-ended; Multiple choice \\
\hline $\begin{array}{l}\text { III. Use of digital } \\
\text { technologies }\end{array}$ & 7 & $\begin{array}{l}\text { Open-ended; Multiple choice; } \\
\text { 5-pt Likert Scale }\end{array}$ \\
\hline $\begin{array}{l}\text { IV. Attitudes toward the } \\
\text { integration of digital } \\
\text { technologies in teaching }\end{array}$ & 2 & Multiple choice \\
\hline $\begin{array}{l}\text { V. Perceptions of how } \\
\text { faculty members } \\
\text { (professors) integrate digital } \\
\text { technologies into their } \\
\text { teaching }\end{array}$ & 5 & Open-ended;Multiple choice; \\
\hline $\begin{array}{l}\text { VI. Self-perception of ability } \\
\text { to use digital technology for } \\
\text { teaching }\end{array}$ & 3 & 5-pt Likert Scale \\
\hline
\end{tabular}

Source: Author.

Part I contains six questions and aims to identify basic information about the participants (i.e., age, gender). Part II includes questions about digital policies in Costa Rica. Part III includes a list of computer and hardware products along with software and communication services to uncover the participants' familiarity with and frequency of use of digital technologies. Part IV investigates participants' attitudes toward using digital technologies for educational purposes. Part V investigates participants' perceptions about the way teacher trainers use digital technology for educational purposes. Finally, Part VI aims to identify pre-service teachers' levels of self-efficacy regarding the educational use of digital technologies.

Descriptive statistics such as mean, standard deviation, and variance were examined along with graphical plots of data distributions. Collected responses to open-ended questions were typed, listed, and categorized following the content analysis

2 The "bachelor" corresponds to four years of minimum compulsory initial training to teach at the preschool and primary level in Costa Rica.

${ }^{3}$ The "licenciatura" corresponds to a fifth non-compulsory year, aimed at specialization. 
technique (Hsieh \& Shannon, 2005).

\section{Results}

In the period from August to September 2016, 341 pre-service teachers voluntarily participated by filling out our questionnaire. The total response rate was $53 \%$ (341/646).

\section{Access to digital technologies and frequency of use by pre-service teachers}

In both universities, pre-service teachers have access to the Internet and to the computers in dedicated rooms. Ninetyeight percent of participants can access the Internet at home. Most (99\%) use digital technologies for their training and professional development.

Figure 1. Pre-service teachers' use frequency of digital technologies (hardware) for their professional development $(1=$ never; 5 = always $)(\mathrm{N}=336)$.

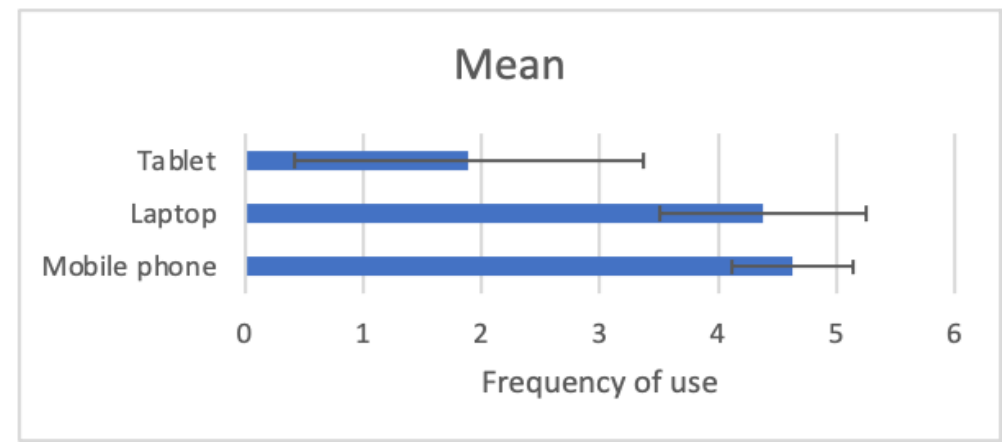

Source: Author.

It is understood (Figure 1) that mobile phones are the foremost device to be used $(\mathrm{M}=4.65)$. The least frequently used technology is the tablet $(\mathrm{M}=1.89)$.

Figure 2. Pre-service teachers' use frequency of digital technologies (software) for their professional development $(1=$ never; $5=$ always $)(\mathrm{N}=336)$.

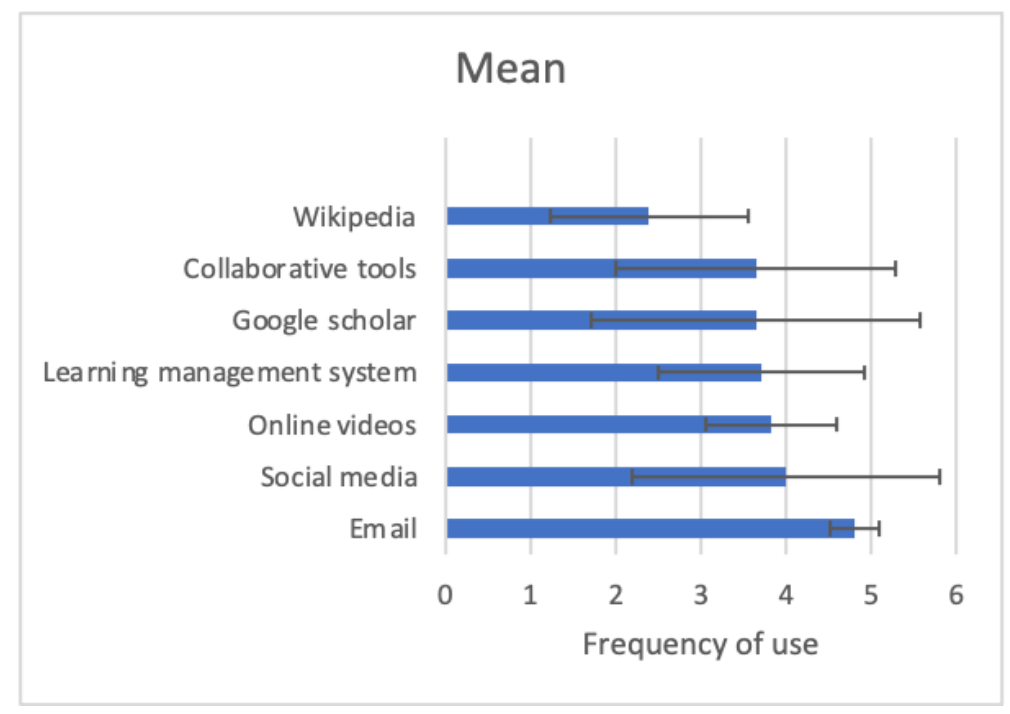

Source: Author. 
The most frequently used technologies are email $(M=4.8)$, social media $(M=3.99)$, videos (especially on YouTube) $(M=3.82)$, learning management systems $(M=3.7)$, Google Scholar $(M=3.64)$, and cooperative tools like Google Docs $(M=$ 3.64). Wikipedia is listed as the least frequently used one $(\mathrm{M}=2.39)$. A majority of respondents also indicated that they use videos on YouTube to better understand some concepts presented by teacher trainers during their university courses. They use social networks to share information and resources among their fellow pre-service teachers more frequently than they use the official educational platform (learning management system, or LMS).

\section{Use of Digital Technologies by Pre-Service Teachers}

An open-ended question allowed participants to list the types of use they engaged in for various digital technologies (Figure 3). Pre-service teachers use mobile phones for both personal and academic use-for example, to look for the meaning of certain words, to take photos of lecture notes, to read for class or for pleasure, or simply to access the Internet.

Figure 3. Textual occurrences about the use of digital technological instruments at university by pre-service teachers $(n=815)$

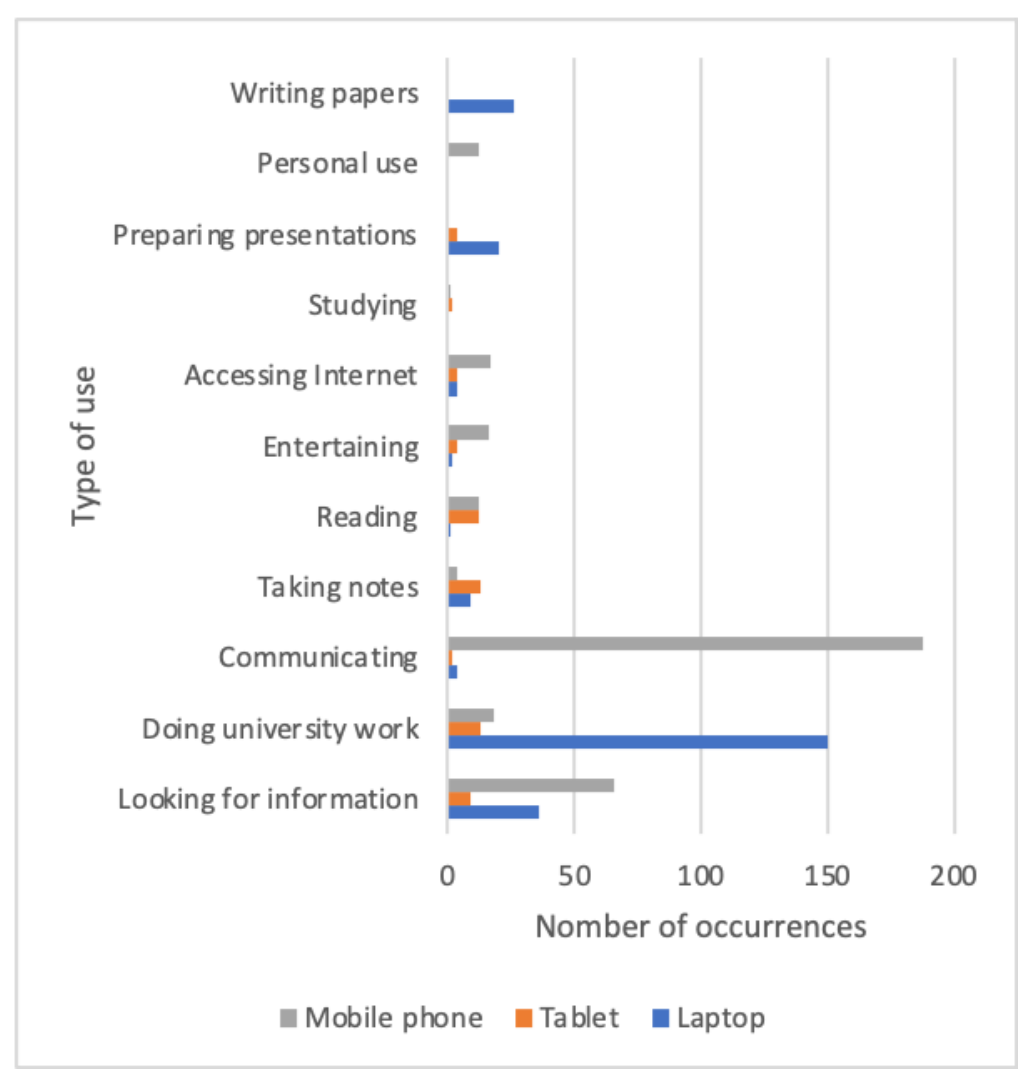

Source: Author.

Note: The figures in this table represent the number of "textual occurrences" (i.e., one occurrence for each coded segment) for each code, for all programs combined (preschool and primary school at National University and at University of Costa Rica). The same student may have responded by listing items belonging to many codes.

Pre-service teachers use their laptops mainly for university work, to look for information, to write essays, or to prepare presentations. The tablet is very little used $(\mathrm{M}=1.89)$, and is mainly used for note-taking or reading (Figure 3$)$.

\section{Reasons for using digital technologies for professional development}

The main advantage to using digital technologies for professional that pre-service teachers mentioned (89\%) is the 
practical use and flexibility, which allows them to reconcile work, family life, and training more easily. They also note (50.4\%) being more motivated to execute different tasks related to academic work. Thirty-seven percent of the respondents mention the development of digital skills as an advantage, and 33.4\% mention simplified communication.

Only $11 \%$ of the respondents perceive collaboration with other students through digital technologies (i.e., Google Docs) as an asset.

Figure 4. Pre-service teachers' perceptions of the advantage of using digital technologies for their professional development (n $=341$ ).

\begin{tabular}{|r|c|}
\hline $\begin{array}{c}\text { Easy access to information } \\
\text { and educational... }\end{array}$ & $89.0 \%$ \\
\hline Increased motivation.... & $50.4 \%$ \\
\hline Development of digital... & $37.0 \%$ \\
\hline Fast communication & $33.4 \%$ \\
\hline Easier collaboration & $11.0 \%$ \\
\hline Other & 1 \\
\hline
\end{tabular}

Source: Author.

More than half of pre-service teachers surveyed (63.9\%) mention distraction because of using digital technologies. Half of the respondents (54.6\%) consider technical problems as a barrier. Some (39.4\%) also perceive the economic factor as a difficulty to accessing digital technologies (i.e., the price of tablets in middle income countries). Some pre-service teachers (35.8\%) consider unreliable information and distrusted resources on the Internet and the loss of time caused by Internet browsing $(4.8 \%)$ as a downside.

Figure 5. Pre-service teachers' perceptions of the disadvantage of using digital technologies for professional development $(\mathrm{n}=$ $341)$.

\begin{tabular}{|r|r|}
\hline \multirow{2}{*}{ Distraction } & $63.9 \%$ \\
\cline { 2 - 2 } Technical problems & $54.6 \%$ \\
\hline $\begin{array}{r}\text { Economical barrier } \\
\text { Non reliable information } \\
\text { on the Internet } \\
\text { Time consuming }\end{array}$ & $39.4 \%$ \\
\hline Other & $35.8 \%$ \\
\hline
\end{tabular}

Source: Author. 
Pre-service teachers' perceptions about the way teacher trainers use digital technology for educational purposes

According to pre-service teachers, professors/teacher trainers use technology mainly to present contents $(\mathrm{M}=1.31)$. The uses to stimulate reflection among pre-service teachers, to promote collaboration or to carry out evaluations are much less important $(\mathrm{M}=2.9)$

Table 3. Professor's/teacher trainer's use of digital technologies ranked in order of importance $(1=$ most important; $4=$ less important).

\begin{tabular}{|l|l|l|l|}
\hline Type of use & $\begin{array}{l}\text { Number } \\
\text { answers }\end{array}$ & Mean & $\begin{array}{l}\text { Standard } \\
\text { deviation }\end{array}$ \\
\hline $\begin{array}{l}\text { Presenting } \\
\text { contents }\end{array}$ & 326 & 1.31 & 0.50 \\
\hline $\begin{array}{l}\text { Promoting } \\
\text { collaboration }\end{array}$ & 292 & 2.88 & 1.00 \\
\hline $\begin{array}{l}\text { Carrying out } \\
\text { evaluations }\end{array}$ & 311 & 2.90 & 0.46 \\
\hline $\begin{array}{l}\text { Promoting } \\
\text { reflection }\end{array}$ & 289 & 2.91 & 0.50 \\
\hline
\end{tabular}

Source: Author.

When asked what digital technologies their trainers recommended for use in teaching, many respondents (32.8\%) point out that they did not receive any recommendation from their trainers about which digital technologies to integrate into teaching. Other respondents listed general statements like using a laptop (36.2\%), a projector (7.9\%), a tablet (4.5\%), videos $(20.7 \%)$, or presentation tools $(6.6 \%)$.

Figure 6. Digital technologies (hardwares and software) teacher trainers suggest pre-service teachers to use for educational purposes $(\mathrm{N}=341)$.

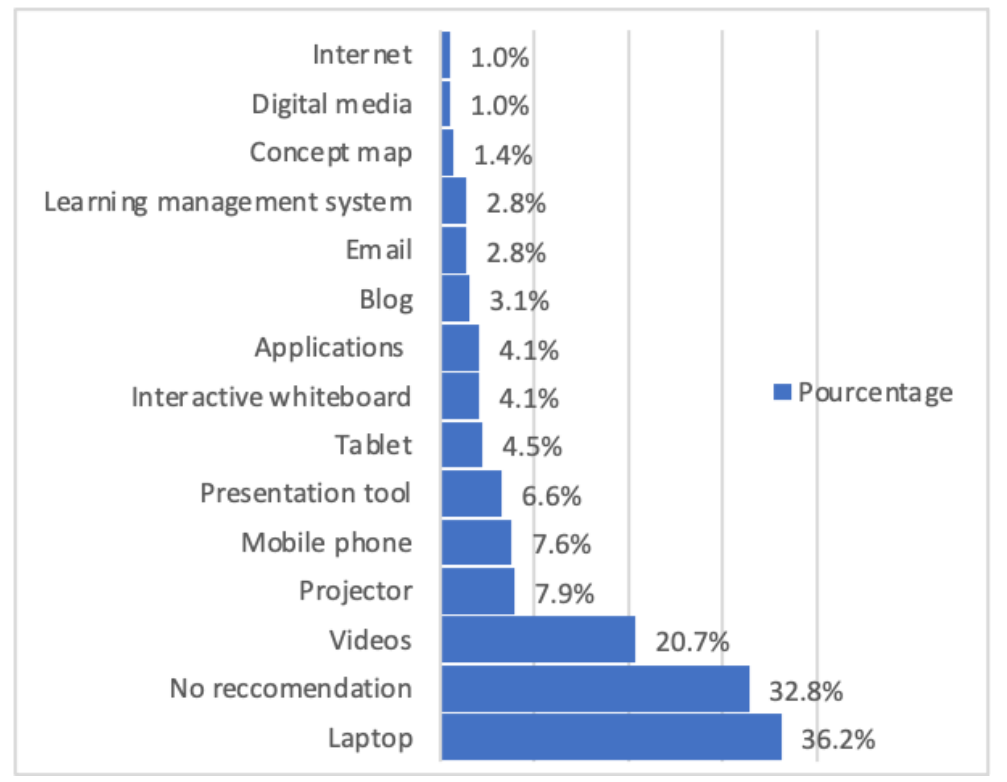

Source: Author. 


\section{Perception of self-efficacy in using digital technologies for educational purposes}

Overall, pre-service teachers perceive their level of self-efficacy to use digital technologies in their teaching as good $(\mathrm{M}=2.91)$ (Figure 7).

Figure 7. Pre-service teachers' self-perceptions of digital technology use efficacy $(4=$ completely agree $; 1=$ completely disagree).

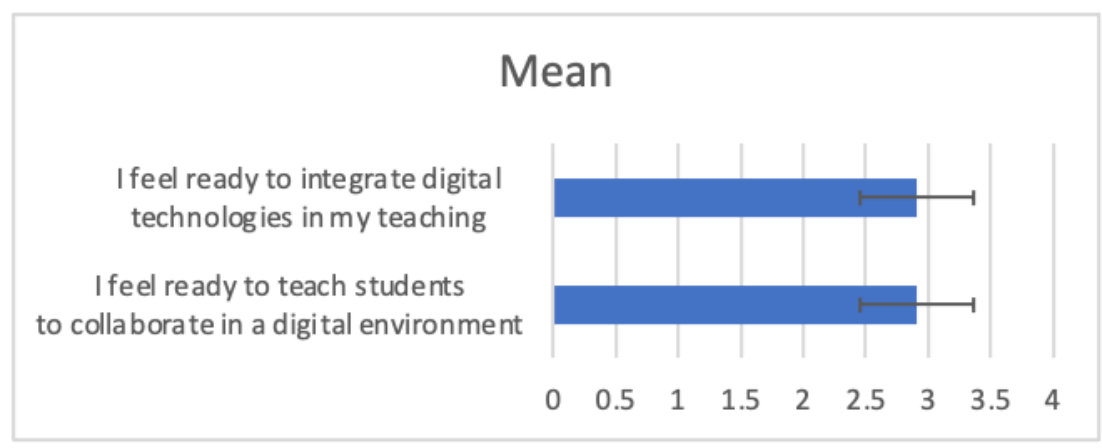

Source: Author.

Thirty-three percent of pre-service teachers who disagree with the first statement attend the fourth year of study and have already completed their internship, and 56\% attend the preschool teaching program. As far as the second statement is concerned, a greater disagreement is observed as well among pre-service teachers attending the fourth year of study and having completed their internship (28\%) and those attending preschool teaching programs (63\%).

\section{Level of self-efficacy with hardware and software}

Pre-service teachers showed a good level of self-efficacy with laptops $(\mathrm{M}=3.29)$, email $(\mathrm{M}=3.27)$, videos $(\mathrm{M}=$ 3.25), learning management systems $(M=2.96)$, and mobile phones $(M=2.95)$. The tablet $(M=2.49)$ and the interactive whiteboard are the tools with which they feel the least confidence.

Figure 8. Level of self-efficacy related to hardware and software.

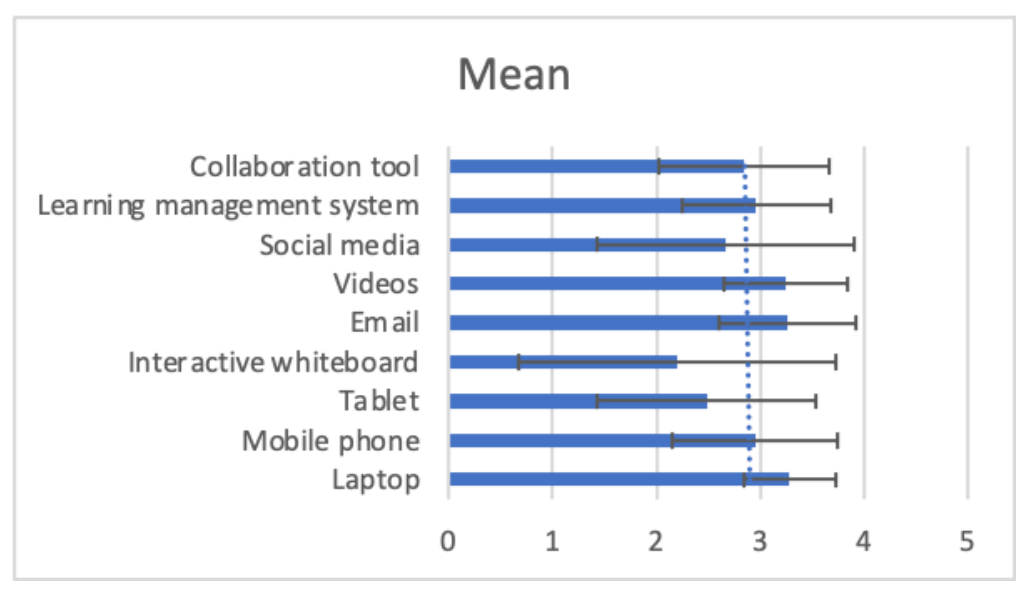

( 4 = completely agree 1 = completely disagree). Source: Author.

\section{The lack of a strong digital transformation culture in faculties of education}

Pre-service teachers do not seem to have an awareness about how digital technologies can be used to improve teaching and learning. They mainly pointed out using digital technologies for communication, information, preparing 
presentations, and university-related work. They did not mention, for instance, using digital technologies or perceiving them as a way to develop creativity (Gresham, 2014), authentic learning experiences (Martin \& Ertzberger, 2013), or to promote individualized learning (Cheon et al., 2012).

Our study points out that the main reasons for using digital technologies are practical use and specific benefits gained from digital technologies — such as their being time-saving and instantly accessible. Teacher trainers' unenthusiastic attitudes regarding digital technologies might explain the lack of classroom use, as suggested by Caneva (2019a), as well as lacking experience, especially with mobile technologies, as outlined by Foulger et al. (2013). Therefore, guidance and counseling that suggests specific digital technologies for educational purpose is either not offered to pre-service teachers or is limited.

Although some teacher trainers are probably innovating their practice and introducing digital activities into their teaching, there seems to be a lack of institutionalized learning from isolated experiments and innovations. Indeed, university policies, do not seem to encourage teacher trainers to use technology in their courses (Caneva, 2019b). This lack of clarity in current policies seems to impact the use of technologies by teacher trainers and pre-service teachers.

As suggested by Calvert (2005), the fact is that in many universities, rewards, recognition, and approval systems don't encourage systematic change or experimentation.

\section{Discussion}

\section{Pre-service teachers feel ready to use digital technologies}

Pre-service teachers feel ready to integrate digital technologies into their teaching and to design digital collaboration activities. We assume that they will probably succeed in this process as explained by the related literature linking positive perception of self-efficacy and successful integration of digital technologies in education (Robertson \& Al-Zahrani, 2012).

Nevertheless, our results call for some improvements to be made to the teacher preparation program; the uses of digital technologies described by pre-service teachers don't highlight educational purposes, such as using educational applications or creating a pedagogical scenario that integrates digital technologies. We can therefore hypothesize that preservice teachers feel ready to use digital technologies for an educational purpose, mainly because they own digital devices and use them frequently for private purposes. However, as suggested by Granjon (2011), owning a digital technology doesn't necessarily mean also possessing the skills and attitudes necessary to fully benefit from it. For instance, using a mobile phone frequently for communication or information retrieval, as outlined in our study, doesn't necessarily imply that a teacher will be able to use it effectively for educational purposes in classroom practice. Our study also highlighted that pre-service teachers' digital activities lacked complexity, as they essentially consist of basic technologies and social media communication as reported by Lei (2014).

\section{A wide use of mobile devices}

Pre-service teachers mainly use their mobile phones and laptops; they send text messages, instant messages, emails, and communicate with these devices. These teachers also share information relevant to their training through social media. It is routine to use the Internet and a mobile phone for a variety of activities in both the private and professional spheres.

However, pre-service teachers do not seem to be effectively prepared to investigate the pedagogical advantages of mobile devices or to make informed decisions, as illustrated by Schuck, Aubusson, Kearney, \& Burden (2013). The reason seems to be that teacher training programs do not make full use of these tools or build upon pre-service teachers' habits that could provide an extension of their learning spaces beyond the classrooms. The programs also fail to prepare them for the technological society, since most of the current jobs require digital skills. Yet, for the teachers to be able to use social media as 
a pedagogical resource, it is necessary, above all, that they understand their pedagogical possibilities. Therefore, it is of vital importance to develop and implement teacher training that enables new ways of thinking about education, educational technology, and innovation in education.

\section{Conclusions}

Our research aimed to identify both the level and frequency of digital technology use and perceived self-efficacy levels of pre-service teachers.

The main results show that pre-service teachers feel ready to integrate digital technologies in their teaching. However, they primarily use these technologies by adopting a passive posture and choosing activities that are tenuously linked to pedagogy. The strong level of efficiency they expressed, therefore, seems related more to their positive attitude toward digital technologies and the time they devote to using them, rather than as a reflection of the pedagogical uses promoted by teacher trainers or from clearly established training policies.

Despite the fact that digital technologies are quite easily accessed in both universities, teacher training about technology integration for pedagogical use seems to lag. We believe teachers need to become digitally literate regarding how such technologies could be effectively used for pedagogical purposes. Models of good practice in the pedagogical uses of digital technologies (e.g., real-world technology integration case studies) could be developed and suggested to pre-service teachers to help them effectively use digital technologies to enhance their teaching and learning.

The development of a shared vision and a digital strategy specifically designed for the department of education could help teacher trainers to adhere to it, to implement it and to integrate digital technology into their teaching. The strategy should provide for a professional development program for teacher trainers aimed at highlighting the possibilities and the added value of technologies to train pre-service teachers in order to enhance their digital literacy skills. To this end, professional development should include peer collaboration and active hands-on learning experiences, enhance reflection on digital technologies, be learner centered, show evidence of student learning, and integrate students' voices and needs.

Among the avenues of future research, we envisage the more in-depth investigation of the use of digital technologies by pre-service teachers and teacher trainers for informal training and for self-learning. Indeed, it emerges from this research that the boundaries between formal and informal learning are blurred because of the use digital technologies for both educational and non-educational purposes (i.e. YouTube).

\section{References}

Allsopp, D. H., Alvarez McHatton, P., \& Cranston-Gingras, A. (2009). Examining perceptions of systematic integration of instructional technology in a teacher education program. Teacher Education and Special Education, 32(4), 337-350. 10.1177/0888406409346144

Area Moreira, M., Hernández Rivero, V., \& Sosa Alonso, J. J. (2016). Models of educational integration of ICTs in the classroom. Comunicar, 24(47), 79-87. https://doi.org/10.3916/C47-2016-08

Arroyo Prieto, L., \& Valenduc, G. (2016). Digital skills and labour opportunities for low-skilled woman.

Boulton, H. \& Hramiak, A. (2014). Cascading the use of Web 2.0 technology in secondary schools in the United Kingdom: identifying the barriers beyond pre-service training. Technology, Pedagogy and Education, 23(2), 151-165.

Bornman, E. (2016). Information society and digital divide in South Africa: results of longitudinal surveys. Information, Communication \& Society, 19(2), 264-278.

Brun, M. (2011). Las tecnologias de la información y de las comunicaciones en la formación inicial docente de América Latina (serie Politicas sociales ${ }^{\circ}$ 172). https://repositorio.cepal.org

Calvert, J. (2005). Distance education at the crossroads. Distance Education, 26(2), 227-238.

Caneva (2019). Facteurs d'adoption ou de rejet des technologies chez les professeurs-formateurs d'enseignants : le cas de l'université costaricienne. Revue internationale des technologies en pédagogie universitaire, 16(1), 15-35. https://doi.org/10.18162/ritpu-2019-v16n1-02 
Caneva (2019). Cinq modèles d'intégration du numérique en formation initiale des enseignants. Une analyse et quelques réflexions. Revue Formation et pratiques d'enseignement en question, 24, 59-81. http://revuedeshep.ch/pdf/24/24-04-Caneva.pdf

Charmarkeh, H. (2015). Les personnes âgées et la fracture numérique de «second degré»: l'apport de la perspective critique en communication. Revue française des sciences de l'information et de la communication, (6).

Cheon, J., Lee, S., Crooks, S. M. \& Song, J. (2012). An investigation of mobile learning readiness in higher education based on the theory of planned behavior. Computers \& Education, 59(3), 1054-1064. doi:10.1016/j.compedu.2012.04.015

Foulger, T. S., Burke, D., Williams, M. K., Waker, M., L., Hansen, R. \& Slykhuis, D. A. (2013). Innovators in teacher education: Diffusing mobile technologies in teacher preparation curriculum. Journal of Digital Learning in Teacher Education, 30(1), 21-29.

Fuchs, C., \& Horak, E. (2008). Africa and the digital divide. Telematics and informatics, 25(2), 99-116.

Furuholt, B., \& Matotay, E. (2011). The developmental contribution from mobile phones across the agricultural value chain in rural Africa. The Electronic Journal of Information Systems in Developing Countries, 48(1), 1-16.

Granjon, F. (2011). Fracture numérique. Communications, 2011/1(88), 67-74. https://doi.org/10.3917/commu.088.0067

Gresham, P. (2014). Fostering creativity through digital storytelling. Metaphor, (1), 47.

Hsieh, Hsiu-Fang \& Shannon, Sarah. (2005). Three Approaches to Qualitative Content Analysis. Qualitative health research, 15, 1277-88. http://dx.doi.org/10.1177/1049732305276687.

Kangai, C. \& Bukaliya, R. (2011). Teacher development through open and distance learning: The case for Zimbabwe. International Journal on New Trends in Education and their implications, 2(4), 124-141.

Jiménez, R. (2014). Educación pública en Costa Rica: políticas, resultados y gasto (Análisis Serie, $\mathrm{n}^{\circ}$ 6). http://academiaca.or.cr

Lei, J. (2014). Digital natives as preservice teachers. Journal of computing in teacher education, 25(3), 87-97.

Lemon, N., \& Garvis, S. (2016). Pre-service teacher self-efficacy in digital technology. Teachers and Teaching, 22(3), 387-408.

Liu, F., Ritzhaupt, A. D., Dawson, K., \& Barron, A. E. (2017). Explaining technology integration in K-12 classrooms: A multilevel path analysis model. Educational Technology Research and Development, 65(4), 795-813.

Ma, J.-H., Vachon, T. \& Cheng, S. (2018). National income, political freedom, and investments in R\&D and education: A comparative analysis of the second digital divide among 15-year-old students. Social Indicators Research, 1-34. 10.1007/s11205-018-2030

Martin, F., \& Ertzberger, J. (2013). Here and now mobile learning: An experimental study on the use of mobile technology. Computers \& Education, 68, 7685 .

Ministerio de Planificación Nacional y Política Económica (2014). Plan nacional de desarrollo 2015-2018 « Alberto Cañas Escalante ». http://presidencia.go.cr

Pereira, A. S., et al. (2018). Metodologia da pesquisa cientifica. [eBook]. Ed. UAB / NTE / UFSM. https://repositorio.ufsm.br/bitstream/handle/1/15824/Lic_Computacao_Metodologia-Pesquisa-Cientifica.pdf?sequence=1

Prasojo, L. D., Mukminin, A., Habibi, A., Marzulina, L., Muhammad, S., \& Harto, K. (2018). Learning to teach in a digital age: ICT integration and EFL student teachers' teaching practices. Teaching English with Technology, 18(3), 18-32.

Roumell Erichsen, E., \& Salajan, F. D. (2014). A comparative analysis of e-learning policy formulation in the European Union and the United States: Discursive convergence and divergence. Comparative Education Review, 58(1), 135-165.

Schuck, S., Aubusson, P., Kearney, M., \& Burden, K. (2013). Mobilising teacher education: A study of a professional learning community. Teacher Development, $17(1), 1-18$.

Pinard, R., Potvin, P. \& Rousseau, R. (2004). Le choix d'une approche méthodologique mixte de recherche en éducation. Recherches qualitatives, 24, 58-80. http://recherche-qualitative.qc.ca/revue

United Nations Educational, Scientific and Cultural Organization (UNESCO). (2011). UNESCO ICT competency framework for teachers. http://hdl.voced.edu.au/10707/217813

United Nations International Childrens Fund (UNICEF) (2013). Integracion de TIC en los sistemas de formacion docente initial y continua para la Education Basica en America Latina. Buenos Aires: UNICEF.

United Nations Educational, Scientific and Cultural Organization (UNESCO). (2012). Information and Communication Technologies in teacher education. Paris: UNESCO.

Sang, G., Valcke, M., Van Braak, J. \& Tondeur, J. (2010). Student teachers' thinking processes and ICT integration: Predictors of prospective teaching behaviors with educational technology. Computers \& Education, 54(1), 103-112. https://www.sciencedirect.com/science/article/pii/S0360131509001870

Schweitzer, E. (2018). Digital divide. Encyclopaedia Britannica.

Tondeur, J., Pareja Roblin, N., van Braak, J., Voogt, J., \& Prestridge, S. (2017). Preparing beginning teachers for technology integration in education: Ready for take-off? Technology, Pedagogy and Education, 26(2), 157-177. 
Research, Society and Development, v. 10, n.1, e11810111436, 2021

(CC BY 4.0) | ISSN 2525-3409 | DOI: http://dx.doi.org/10.33448/rsd-v10i1.11436

Vaillant, D. (2013). Integración de TIC en los sistemas de formación docente inicial y continua para la Educación Básica en América Latina. UNICEF. http://researchgate.net/profile/Denise_Vaillant

Vivian, R., Falkner, K., \& Falkner, N. (2014). Addressing the challenges of a new digital technologies curriculum: MOOCs as a scalable solution for teacher professional development. 